\section{Chapter}

[1]

\title{
Biological diversity: Introduction, values, threats and conservation measures
}

\author{
Sheetal Rani, Sonika Kumari, \\ Pankaj Kumar and Vinod Kumar*
}

Agro-ecology and Pollution Research Laboratory, Department of Zoology and Environmental Science, Gurukula Kangri (Deemed to be University), Haridwar 249404 (Uttarakhand), India

\section{Abstract}

Earth is the only know planet to have life till date. However, life on the earth has evolved from microscopic organisms (microbes) that left signals of their presence in rocks about 3.7 billion years old to the present time's complex plant and animal forms. Earth has created different forms of life in four different patterns of evolution viz., convergent evolution, divergent evolution, parallel evolution, and coevolution. From these evolutions, different types of animals and plants have emerged as a result of continuous but very slow changes in the genetic materials (RNA and DNA). At present, earth's species range from 10 million to 14 million out of which plants $(17 \%)$, protists $(4 \%)$ prokaryotes $(0.3 \%)$, fungi $(4.7 \%)$, insects $(54 \%)$, and other animals $(20 \%)$ are major candidates. All these species play an important role in earth and it's environmental sustainability with various values. In this, recently emerged anthropogenic activities has contributed in rapid vanishing of biodiversity affecting mostly all compartments of life. However, various steps are being taken at national and international level such as creation of national parks, wildlife sanctuaries, conservation reserves, community reserves, biosphere reserves, gene banks, etc. This chapter describes the status and importance of biodiversity conservation in present scenario. 


\section{Introduction}

Biodiversity originates from Greek word Bios means life and Latin word Diversitas means form or variety. It refers to different forms of life (plants, animals, fungi and microbes) on planet Earth. The term 'biological diversity' was coined by Thomas Lovejoy in 1980 and the term 'biodiversity' was coined by Walter G. Rosen in 1986 at National Forum on Biodiversity held in Washington (Sarkar, 2019). Biodiversity or biological diversity can range from smallest known life forms Nanobes with diameter 20-150 nm, smallest known bacteria (Unwins, 1999) to blue whale having length up to 110 feet and from extreme cold to extreme hot. Different form of life exists at any extreme conditions with which one can depict the range of diversity on the Earth. Biological diversity has no particular/ standardised definitions. Different definitions were given from time to time to explain biodiversity. Biodiversity or biological diversity defined as the variation among different genetic, species and ecosystem levels in the biological system (Bartkowski et al., 2015).

"Biological diversity is defined as the variability among all the sources including, inter alia, land (terrestrial), marine and aquatic ecosystems and the ecological complexes of which they are part it includes diversity within species, between species and of the ecosystems": Convention on Biological Diversity, 1992 (signed by United Nation Earth Summit held in Rio de Janeiro).

According to Noss (1990), "Biodiversity is not only the variability among genetic, species and ecosystem level in a defined area but it should also include the various interspecific interactions, biogeochemical cycles and natural disturbances. It should include the range of diversity indices and quantitative factors along with quantitative factors should be considered as an indicator for biological disruption". Biodiversity is defined as the abundance, number, composition, interactions, spatial distribution, population, species, communities and their functions, genotypic and phenotypic traits, landscape units in a biological system (Díaz et al., 2009). It is the interaction between different types of diversities like genetic, species and ecosystem diversity.

\section{Types of biodiversity}

Generally, the biological diversity has three types, these includes genetic diversity, species diversity and ecosystem diversity (Figure 1). The detailed description of genetic diversity, species diversity and ecosystem diversity are as follows:

Genetic diversity: It refers to the variation in the genetic constitution within a species or within a population. Every organism in this world is different from another in their genetic material. For example, in humans even twins are not exactly similar in their genetic makeup and shows lots of diversity from one another. Likewise, genetic diversity of rice, barley, maize etc. shows variation in the same species. The same species shows difference in their genetic makeup, color, size aroma, shape and 


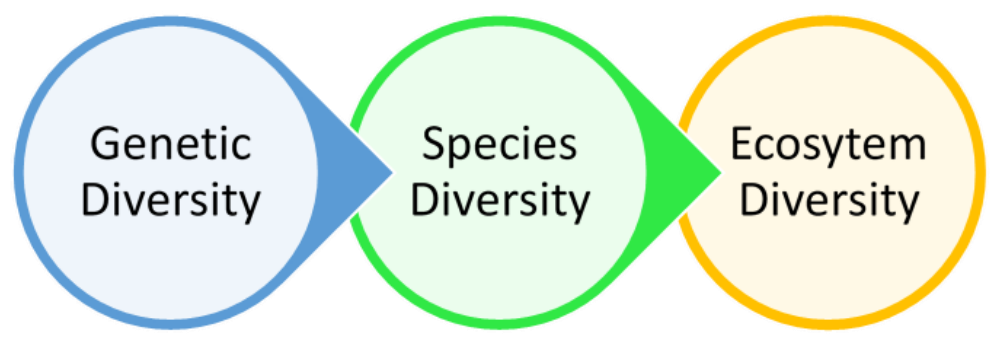

Figure 1. Types of biological diversity.

nutrient content. Due to the genetic diversity species are able to show adaptation and respond to the environmental changes. It is also helpful in evolution and speciation (Carvalho et al., 2019).

Species diversity: It is the biological diversity at the most basic level. Species exists in large groups with different physical and biological characters. These species function individually or in a group in the food web. Species interact with each other through different interactions (competition, mutualism etc.) which collectively play an important role in ecosystem dynamics. Species diversity is measured by species richness and relative abundance (White et al., 2018).

Ecosystem diversity: An ecosystem consists of both living and non- living components and their interactions with each other. Ecosystem diversity is defined as the diversity among different ecosystems in a region. For example, ecosystems like mountains, desert, grasslands, mangroves show diversity. This type of ecological diversity is more stable and productive as they are capable to tolerate unfavourable environmental conditions (Brierley et al., 2016; Kumar et al., 2019).

\section{Biodiversity of India and the world}

India consists of 10 major biogeographic zones and 27 biogeographical provinces based on their distinctive biota. One biotic province or biogeographical province is different from another in their flora and faunal composition (Table 1). There are over 8.74 million species of eukaryotes on world's land and about 2.21 million species of eukaryotes in ocean water while approximately 10,000 species of prokaryotes on land and out of which 1300 are marine prokaryotes predicted on Earth. There are about 7.7 million species of animals and over 300,000 species of plants (Mora et al., 2011). In this world there are about 1,399,189 species which belongs to kingdom Animalia and in India over 92,873 species belong to this kingdom which constitute $6.64 \%$ (ZSI, 2014). There are about 317,950 plants species present in this world. In India there are over 29,015 plant species with 9.13 percent (BSI, 2013). Total number of Insecta, Mammalia, Aves, Reptilia, Pisces, Animalia, Protista in India and the world is given in Figures 2 and 3. There are about 7200 species of Algae, 2500 species of Bryophytes, 1269 species of Pteridophytes, 75 species of Gymnosperms and over 18,000 species of Angiosperms. About 9.13 percent floral diversity is found in India and Angiosperms contributes to over 27\% (Figure 4). 
Table 1. Distribution of biogeographic zones in India (Source: MoEF, 2009; Singh and Chaturvedi, 2017).

\begin{tabular}{ll}
\hline Biogeographic zone & Biogeographic province \\
\hline Trans-Himalayas & Ladakh mountains \\
& Tibetan Plateau \\
& Trans-Himalayan: Sikkim \\
& North-Western Himalaya \\
Himalaya & Western Himalaya \\
& Central Himalaya \\
& Eastern Himalaya \\
Indian desert & Kutch \\
& Thar Desert \\
Semi-arid & Punjab plains (semi-arid) \\
& Gujrat, Rajputana \\
Western ghats & Malabar Plains \\
& Mountains of Western Ghats \\
Deccan peninsula & Central Highlands \\
& Chotta Nagpur \\
& Eastern Highlands \\
& Central Plateau \\
The Gangetic Plains & Deccan South \\
& Lower Gangetic plains \\
The Coasts & Upper Gangetic Plains \\
& West Coast \\
North-east India & East Coast \\
Islands & Lakshdweep \\
& Assam plains \\
& Shillong Plateau \\
& Andamans \\
& Nicobars \\
&
\end{tabular}

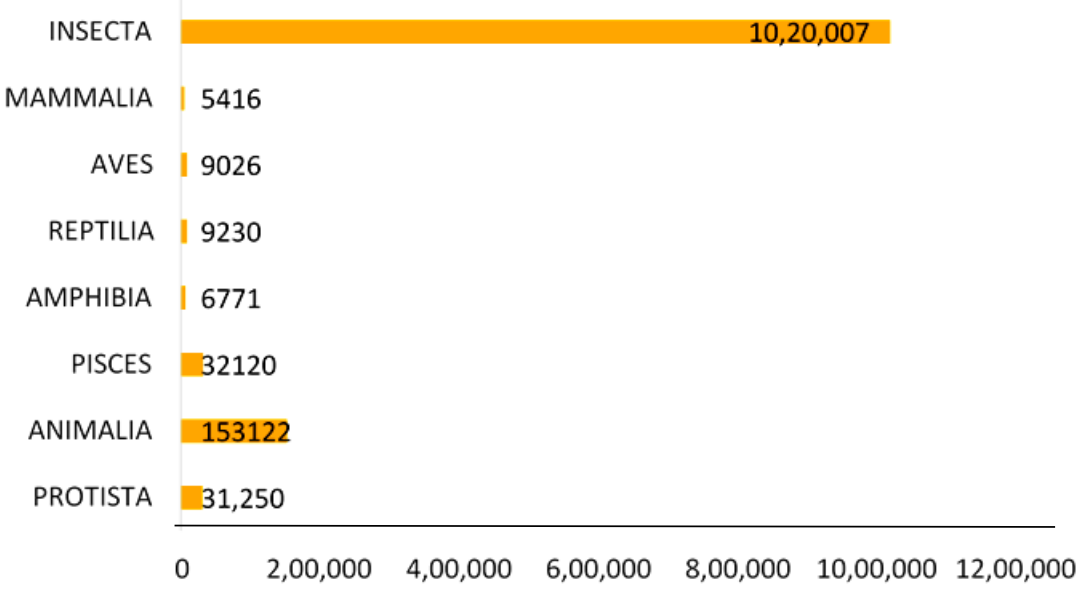

Figure 2. Taxonomic group species of the world (Zoological Survey of India, ZSI, 2014). 


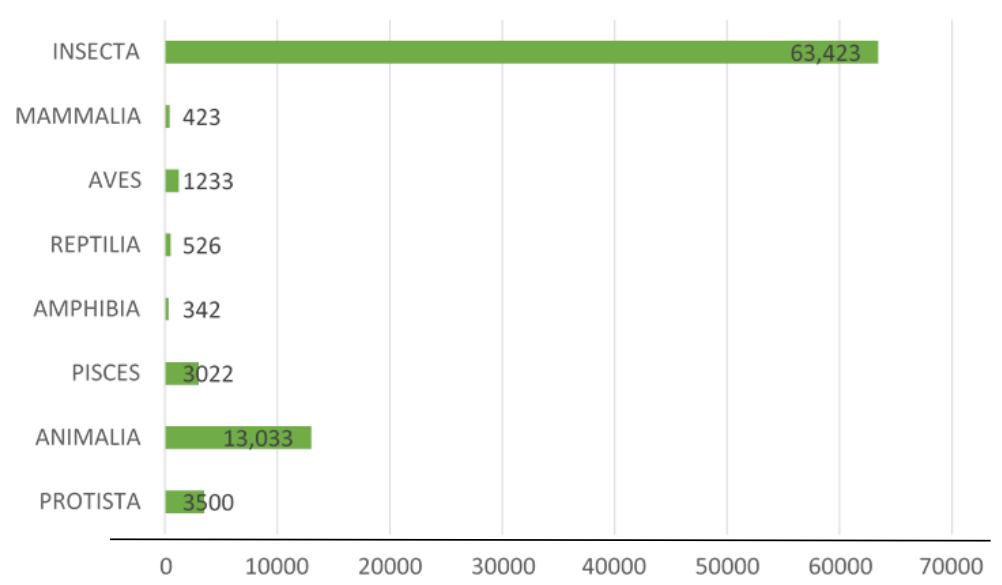

Figure 3. Taxonomic group species of India (Zoological Survey of India, ZSI, 2014).

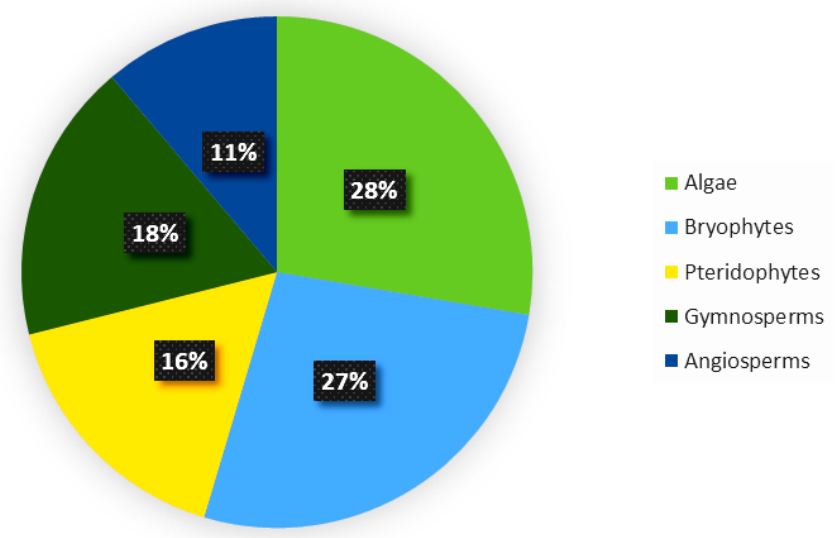

Figure 4. Percentage of floral diversity in India (Source: Botanical Survey of India, BSI, 2013).

\section{Biodiversity hotspots}

Biodiversity hotspots are the areas that are extremely rich in flora and fauna and have a high level of endemism, which includes flora and fauna which are under the threat of getting endangered. There are mainly two criteria to be checked to qualify a region under the category of a biodiversity hotspot. (a) It must have at least 1500 or $0.5 \%$ species of vascular plants that are endemic to the region. (b) It has to have lost $\geq 70 \%$ of its original native habitat and must be in the threatened list of IUCN (Johnson et al., 2015). Based on these criteria around 36 areas of the world qualify as biodiversity hotspots. These covers just 2.5\% of Earth's land surface but it constitutes more than half of the world's plant species as endemics i.e., belonging to the particular place only and nearly $43 \%$ of mammal, bird, reptile and 
amphibian species as endemics. Presently there are 36 biodiversity hotspots (Table 2). These areas are of extreme importance and need utmost protection (Huang et al., 2018). The 36 biodiversity hotspots of the world have been classified on the basis of location which are North and Central America, Europe and Central Asia, Africa, Asia and Australia and South America.

Table 2. Distribution of biodiversity hotspots in the world (Source: Conservation International/ Biodiversity Hotspots (https://www.conservation.org/).

\begin{tabular}{|c|c|}
\hline Biodiversity hotspots & Location \\
\hline Atlantic Forest & Argentina, Paraguay and parts of Brazil \\
\hline California Floristic Province & California, USA \\
\hline Cape Floristic Region & Southern tip of South Africa \\
\hline Caribbean Islands & East of Central America \\
\hline Caucasus & $\begin{array}{l}\text { Near border between Europe and Asia, separating the } \\
\text { Black and Caspian seas }\end{array}$ \\
\hline Cerrodo & Central Brazil \\
\hline $\begin{array}{l}\text { Chilean Winter Rainfall - Valdivian For- } \\
\text { ests }\end{array}$ & $\begin{array}{l}\text { Central North of Chile, to the Western regions of Argenti- } \\
\text { na }\end{array}$ \\
\hline Coastal Forests of Eastern Africa & Eastern cost of Africa \\
\hline East Melanesian Islands & North East of Australia \\
\hline Eastern Afromontane & East African Rift from the Red Sea to Zimbabwe \\
\hline Forest of East Australia & Eastern Coast of Australia \\
\hline Guinean Forests of West Africa & Coastal Western Africa \\
\hline Eastern Himalaya & Parts of India, China, Bhutan, Tibet and Myanmar \\
\hline Horn of Africa & Northeastern Africa \\
\hline Indo-Burma & $\begin{array}{l}\text { Parts of Bangladesh, India, Myanmar, China, Cambodia, } \\
\text { Vietnam, Thailand and Malaysia, Hainan Island and An- } \\
\text { daman Island }\end{array}$ \\
\hline Irano-Anatolian & $\begin{array}{l}\text { Parts of Armenia, Azerbaijan, Georgia, Iraq, Iran, Turkey } \\
\text { and Turkmenistan }\end{array}$ \\
\hline Indian Ocean Islands & $\begin{array}{l}\text { Surrounding Madagascar, Comoros, Mauritius and Sey- } \\
\text { chelles }\end{array}$ \\
\hline Japan & Northern Pacific Ocean \\
\hline Madagascar & Southeast Coast of South Africa \\
\hline Madrean Pine-Oak Woodlands & Southern part of USA \\
\hline Maputalanad-Pondoland-Albany & South Eastern Coast of South Africa \\
\hline Mediterranean Basin & Surrounding the Mediterranean Sea \\
\hline Mesoamerica & $\begin{array}{l}\text { Belize, Guatemala, Central Mexico, Nicaragua and North- } \\
\text { ern Costa Rica }\end{array}$ \\
\hline Mountains of Central Asia & $\begin{array}{l}\text { It extends through Afghanistan, China, Kazakhstan, Kyr- } \\
\text { gyzstan, Tajikistan and Uzbekistan in Central Asia }\end{array}$ \\
\hline Mountains of Southwest China & Includes Tibet, Sichuan, Qinghai, Gansu and Myanmar \\
\hline New Caledonia & South Pacific Ocean \\
\hline New Zealand & Southwest Pacific Ocean \\
\hline Philippines & Southeast Asia \\
\hline Polynesia-Micronesia & Southern Pacific Ocean \\
\hline
\end{tabular}


Table 2. Continued...

\begin{tabular}{ll}
\hline Biodiversity hotspots & Location \\
\hline Southwest Australia & Southwest part of Australia \\
Succulent Karoo & Coastal Region of South Africa \\
Sundaland & $\begin{array}{l}\text { Southeastern Asia comprising the Malay Peninsula, } \\
\text { Bomeo Island, Java Island and Sumatra Island along with } \\
\text { their smaller surrounding Islands. }\end{array}$ \\
& South America: Parts of Andes Mountains \\
Tropical Andes & The Galapagos Island and Pacific Coast of South America \\
Tumbes-Choco-Magdalena & Eastern Indonesia \\
Wallacea & Indian Peninsula and South of India \\
Western Ghats of India and Islands of Sri & \\
Lanka & \\
\hline
\end{tabular}

\section{Biodiversity hotspots in India}

India is rich in biological diversity. The four hotspots present in the Indian subcontinent are Western Ghats of India and Sri Lanka, The Himalayas, Indo- Burma and Sundaland (Sivaperuman et al., 2018).

Western Ghats of India and Sri Lanka: These are older than Himalayas, formed by the erosion of Deccan plateau. Geological evidences indicate that they are formed during erosion of Gondwana subcontinent. Western Ghats are covered under six states of India these are Maharashtra, Gujrat, Goa, Karnataka, Kerala and Tamil Nadu. They are the continuous range of mountains along the western edge of peninsular India which covers the area of $160,000 \mathrm{~km}^{2}$ in a stretch (Yakovlev and Zolotuhin, 2021). The Western Ghats are considered as UNESCO World Heritage Site and one of the "hottest biodiversity hotspots" of the world. These are highly rich in biodiversity and shows high endemism. The western Ghats covers less than $6 \%$ area of India but constitutes over $30 \%$ of all the floral and faunal diversity found in India (Myers et al., 2000; Bawa et al., 2007). These are present near ocean so good amount of rainfall is received in this region. Different varieties of forests are present in this region which are Evergreen forests, Semi Evergreen forests, Moist Deciduous Forest and Dry Deciduous Forest. The other type of vegetation includes, Savana, High rainfall Savana, Scrub jungles, Peat bogs, Sholas and Myristica Swamps. Over 5,916 plant species out of which 3,049 are endemic to Western Ghats of India and Sri Lanka. In addition to plants, 140 species of mammals (18 are endemic with 12.9 $\%$ endemism), 191 species of fishes with $72.8 \%$ endemism, 178 amphibian species with $73 \%$ endemism, 458 species of birds with $7.6 \%$ of endemism and 267 reptile species having $65.2 \%$ endemism found in this biodiversity hotspot (Figure 5) The Nilgiri Hills are located in the Western Ghats and over the population of 10,000 elephants found in this region. The southwestern part of Ghats is also very important for the conservation point of view of tigers as $10 \%$ of world's tigers found here (Myers et al., 2000). The Himalayas: The Himalayas are the youngest and one of the highest mountain ranges. These are formed by the collision between two continental plates, Indian plate and Eurasian plate about 40-50 million years ago and this collision between the plates is active today (Rana et al., 2021). 
Table 3. Biological diversity and endemism in the Himalayas biodiversity hotspot (Source: www.cepf.net).

\begin{tabular}{llll}
\hline Species group & $\begin{array}{l}\text { Total number of } \\
\text { Species }\end{array}$ & Endemic species & Endemism (\%) \\
\hline Plants & 10,000 & 3,160 & 31.6 \\
Mammals & 300 & 12 & 4 \\
Birds & 980 & 15 & 1.5 \\
Reptiles & 175 & 50 & 28.5 \\
Amphibians & 105 & 40 & 38 \\
Freshwater Fishes & 269 & 33 & 12.2 \\
\hline
\end{tabular}

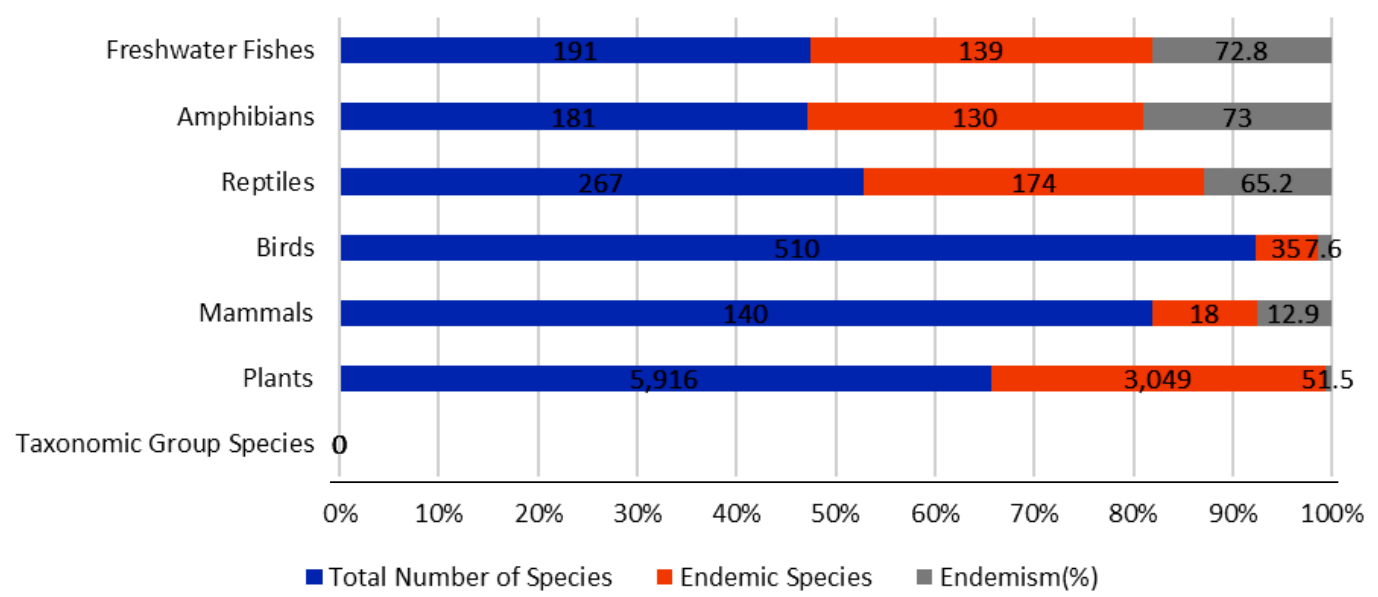

Figure 5. Biological diversity and endemism in the Western Ghats of India and Sri Lanka (Source: www.conservation.org).

The Himalayas comprise of eastern and central Nepal, Bhutan, North-East India (West Bengal, Sikkim, Arunachal Pradesh and Assam), North-West India (Kumaon, Gharwal and northwest Kashmir), northern Pakistan, southeast Tibet and northern Myanmar. The Himalayas are the source of freshwater and store huge amount of water in the form of glaciers so are popularly known as water towers. Mount Everest $(8848.86 \mathrm{~m})$, the world highest mountain is located in the Himalayas (Kiran et al., 2021). The Himalayan hotspot covers an area 741,706 square kilometers. The climatic and altitudinal variation in Himalayas leads to different types of ecosystems. Total $112,578 \mathrm{~km}^{2}$ is the are protected under the hotspot out of which $77,739 \mathrm{~km}^{2}$ is classified as an area of higher level of protection under categories of 1-4 (ENVIS Resource Partner on Biodiversity/ Biodiversity Hotspots: http://www.bsienvis.nic.in/). This region supports 163 endangered species (Kiran et al., 2021). It is the home of Wild Asian Water Buffalo, One-horned Rhino, Snow Leopard, Musk deer, Himalayan tahr, Blue sheep, Black bear, Chir pheasant, Himalayan monal and Western tragopan. The hotspot consists of 300 mammals, 980 birds, 175 reptiles, 105 amphibians and 269 freshwater fishes (Table 3). 
Over 10,000 plant species are present in this biodiversity hotspot out of which 3160 are found nowhere else with $31.6 \%$ endemism. In Indian region of Himalayan hotspot over 6000 plant species are found out of which nearly 2000 are endemic. It consists of various plants of great economic value like Rhododendron, Bamboo, Orchids, Cinnamomum, Pinus, Banana, Citrus, Rice, Ginger, Jute, Sugarcane, Willow etc. (Gupta et al., 2020).

Indo-Burma region: Indo-Burma biodiversity hotspot is located in South Asia and covers an area of 2,373,057 square kilometers. From Indian side this hotspot covers an area of North-East India (except Assam) including Andaman and Nicobar Island excluding Himalayan region. Outside India it is primarily located in Southern China, Laos, Vietnam, Cambodia, Thailand (except northern side), and Myanmar (except southern side) (Kano et al., 2016). It is one of the most threatened biodiversity hotspots and only five percent of original habitat remaining so it needs primary focus for conservation majors. All the 20 species of endemic primates which are found only in Indo-Burma region are endangered. Indo- Burma biodiversity hotspot shows high diversity due to different types of ecosystems including tropical or sub- tropical dry broadleaf forests, mixed forests, temperate forests, dry evergreen forests, deciduous and mangroves (Basumatary et al., 2015). At several places patches of woodlands and shrublands outcrops on karst limestone, scattered forest in coastal areas along with water filled grassland and floodplain swamps are some more distinctive type of vegetation found in this hotspot (Stephan et al., 2015). This region is dominated by valuable timber species, Palm trees, Slipper Orchids (33 species), Rhododendron spp. etc. Fauna of this hotspot mainly consists of Large-antlered Muntjac, Pangolin (most trafficked animal in the world), Grey-shanked Douc, Leaf Deer, Jullien's golden carp and White-eyed river-martin. This hotspot is a home for many species of plants, animals, amphibians, Aves, freshwater fishes and reptiles (Figure 6).

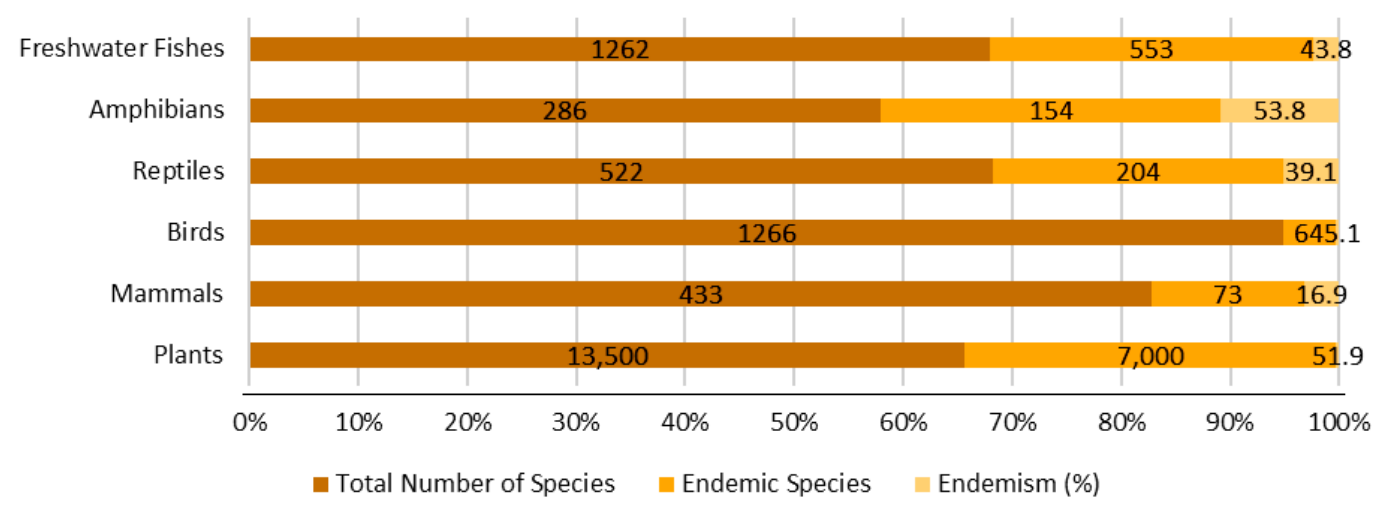

Figure 6. Biological diversity and endemism in the Indo-Burma biodiversity hotspot

(Source: bsienvis.nic.in). 
The Sundaland: In Pleistocene period, the Sundaland hotspot isolated from mainland Asia as the change in sea level occurs during this period. More than million years ago it was the part of mainland Asia. The Sundaland biodiversity hotspot lies in southeast Asia including, western half of Indonesia, Singapore, Philippines, Brunei, small part of southern Thailand and all part of Nicobar Islands (Indian side). This is extended to an area of over 1,500,000 square kilometres dominated by the largest islands of the world Borneo (third) and Sumatra (sixth) (Verma et al., 2020). The Sundaland hotspot characterised by reefs, high mountain terrains, volcanoes, mangroves, alluvial plains, swamps and shallow coastal water. The Sundaland biodiversity hotspot is joined by three other biodiversity hotspots. From northeast it is connected to Philippines hotspot, east side of the Sundaland hotspot is bordering to Wallacea hotspot and Indo-Burma hotspot is joined to the northeast (Hu et al., 2021). Sundaland biodiversity hotspot is very rich in biological diversity and it is the home of some of the iconic species like Rhinos, Orangutans (Sumatran and Borneo). It includes different types of ecosystems ranging from high mountain ranges with very less vegetation to low-land rainforests dominated by family Dipterocarpaceae. The other type of forest including mangroves forest, swamp forests, beach forests and sub-alpine forests are also found in this hotspot. The Sundaland biodiversity hotspot consists of more than 50,000 endemic species of plants with $60 \%$ endemism. Over 650 species of plants are found in the Nicobar Islands. This hotspot consists of various species, of plants, mammals, birds, reptiles, amphibians and freshwater fishes as shown in Figure 7 with endemism of $60 \%, 45.3 \%, 18.5 \%$, $53.8 \%, 80.3$ and 36.8, respectively (Sholihah, 2020).

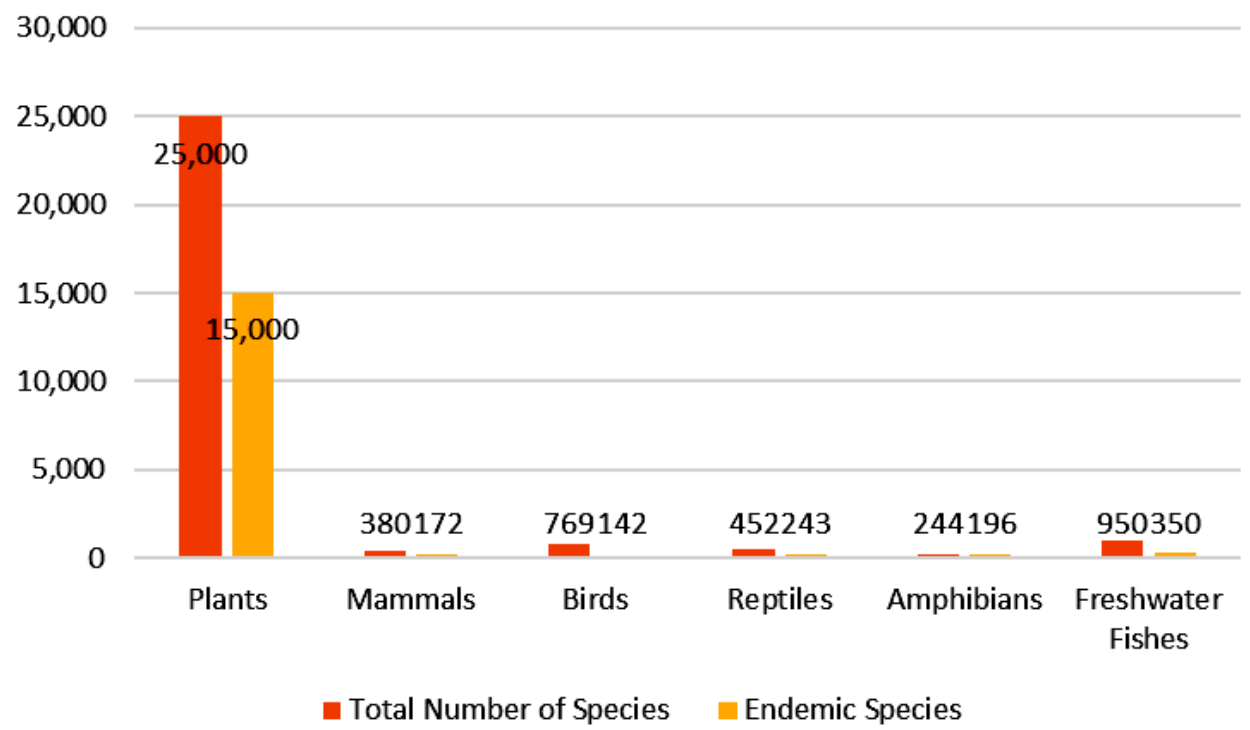

Figure 7. Biological diversity and endemism in the Indo-Burma biodiversity hotspot (Source: www.bsienvis.nic.in; Venkataraman and Sivaperuman, 2018). 


\section{Values of biological diversity}

Biological diversity plays a very crucial role for the survival of human beings on earth. The humans directly or indirectly depend upon biological diversity for fulfilling almost every need in their life such as food, energy, medicine, housing etc. Biological diversity helps to maintain the ecological balance (Dietsch et al., 2016). It provides various ecological services and vital for maintaining, preserving and restoration of various ecological process. Biological diversity is helpful in maintaining biogeochemical cycles, maintaining the flow of water bodies like river and streams all-round the year, soil formation, control in floods, prevention from soil erosion, circulation of air globally and its cleansing, nutrient recycling and life support of all the species. Following are the direct and indirect values of biological diversity (Seddon et al., 2016).

\section{Direct values of biological diversity}

Consumptive use value: The consumptive use of values includes the direct consumption of resources without passing through the market. Biological diversity provides direct food, shelter, medicines, proteins, enzymes, fats, macro and micro nutrients, beverages, specimens for educational and scientific purposes, tourism and raw material for various commercial purposes (Thapa et al., 2020). For example, Aloe Vera is directly consumed for its medicinal properties, timber is used for fire and animals are consumed directly after hunting.

Productive use value: Productive use value is the value which put on marketable products. The different professionals from various fields studies biological diversity for its productive values. The agricultural scientist uses biological diversity for improving the yield and quality of crops. The biotechnologist studies different genetic properties of plants, animals and microbes. The best traits can be selected from the organism with which new improved (disease resistant and high yield) variety of crops can be produced. It also helps to develop better livestock (high nutrient value and fast growth) (Jactel et al., 2018). Pharmacist use biological diversity as a raw material for the production of various plants based and animals-based drugs.

\section{Indirect values of biological diversity}

Social values: From the ancient time people used to protect biodiversity for their needs. Ancient people used to value biological diversity specially in India, people worship various plants, animals, waterbodies, stones and mountains as they are helpful for their survival and have high esteem. Earlier needs were few as less population so most of biological diversity is conserved (Griffiths et al., 2019). Still many tribal people directly depend on forests for their daily needs. Many indigenous people are helpful for conserving biological diversity as they used to cut only old tree branches for wood and only the leaves of young trees are used only for livestock. Modern people are least concerned about the conservation of biological diversity. They only care about their own usage and try to grab it as much as one can at once and exploit it which sometimes leads to irreversible loss (Evers et al., 2018).

Ethical and moral values: It is the moral duty of human beings to conserve biological diversity. Planet 
earth belongs to every species in this world and humans have no right to harm any species if it is of no use to them. Ethical values are related to conservation of biological diversity from animal trafficking, smuggling, illegal activities like cloning, inhuman treatment with animals, biopiracy, unauthorized animal testing, poaching, desertification and uncontrolled deforestation (Antonelli and Perrigo, 2018). To meet the high demand of resources due to population explosion benefits are given more importance rather than ethics and moral values

Aesthetic values: Biological diversity is secret for the beauty of our planet. The different kinds of plants, animals, flowers and birds provide great aesthetic value. Various recreational activities are linked to it like bird watching, butterfly parks, river rafting, national parks, aquarium and botanical gardens (Collins et al., 2017).

Economic values: Biological diversity has a great economic value; food is the basic necessity which is the product of it. The agricultural sector, various industries depend upon biodiversity products. The revenue generated from biodiversity products is essential for the growth of any country (Hanley et al., 2015).

Scientific values: Various research work has been done on many species of plants, animals, insects etc. and many has to be done to attain knowledge. This scientific knowledge can be utilized for the things which of great value to human beings (Titley et al., 2017). During the COVID-19 pandemic we have learned various lessons for conservation of biodiversity. An enzyme used in COVID-19 testing is extracted from a bacterium, Thermus aquaticus which was discovered in a geyser in Yellowstone National Park, US (Buchanan, 2021).

\section{Threats and causes of biological diversity loss}

Almost every corner on the earth where humans have footprints due to this is everything is under threat. Due to population explosion and cattle heads, the demands for food, water, land and energy increased exponentially. To meet these demands every resource is being exploited. Due to overuse and uncontrolled use of resources and humans induced climate change out of 8 million species nearly 1 million species are under the category threatened and can extinct within decades (UN report, 2019).

The major threats to biological diversity are as follows:

Invasive species: These are the species which are exotic that is not native to a particular place. The introduction of invasive species causes harmful effects on the native species. These have the more potential to adapt and grow due to which the consume the energy and nutrients faster thus threating the local biodiversity. Invasive species are introduced intentionally or by an accident but once they establish itself, they grow very rapidly and other local population of species decline rapidly which can cause extinction (Bailey, 2015).

Climate change: Climate change have huge impact on biodiversity at all the levels. The human induced climate change causes increase in greenhouse gases, global warming, flash floods, changes in precipitation pattern, droughts and many more at much faster rate. All these factors impact biological diversity directly or indirectly. Due to extreme heat the incidents of forest fires are increasing which 
causes great loss to biodiversity (Stoll-Kleemann and Schmidt, 2017). The life cycle of many plants and animals' species is affected with change in seasons and climate patterns. Many developmental processes of various organism depend upon heat or cold (temperature changes) or the length of day. Due to climate change these cycles and patterns are influenced which can cause extinction of various species and impact abundance, distribution and range of species (Kumar et al., 2009).

Environmental pollution: The environmental pollution is a major threat and primary cause of loss of biological diversity. The air, water, soil, noise and radioactive pollution effects the biodiversity. The industries release various toxins which get mixed into air, water and soil and organisms which consume anything contaminated with it die (Brei et al., 2016). The billion tonnes of microplastic particles and plastic products are flowing along with water and it is killing many marine organisms. The noise pollution effects the reproductive patterns of birds. Collectively it is impacting species diversity, weakening ecosystem, impacting food chain and disrupting ecological balance (Gonzalez et al., 2016).

Land and sea use change: The use of forest land is done for agricultural purposes and for this forest are cleared. It is the cause for $80 \%$ of deforestation. It caused the huge impact in forest ecosystem as it results in habitat loss and degradation. In North America over 3 million birds lost in past 50 years due to habitat loss and pesticides (WWF living Planet Report, 2020). The various wetlands are drained out for land. Oceans are used for various business activities which causes huge impact on marine ecosystem (Oliver and Morecroft, 2014).

Overexploitation: Humans are taking everything in excess and most of it remains unused or wasted. This is causing huge pressure on natural resources as nature is not able to replenish as compared to amount, we are taking from the nature. The species which are of human use are overexploited instead of using it in a sustainable manner. Taking one or few species can cause impacts on other dependent population and it creates ecosystem imbalance. Over fishing is one of the example of species overexploitation and according to a study, all the fishes may extinguish till 2050 (de Souza and Prevedello, 2020).

\section{International Union for Conservation of Nature (IUCN)}

International Union for Conservation of Nature (IUCN) was founded in 1948. It is one of the world's largest environmental organizations with more than 1400 member organizations, 200 plus governments and nearly 9000 non-government organizations. Its headquarters are located in Gland, near Geneva, in Switzerland. In 1992, IUCN is given Official Observer Status at United Nations General Assembly (Alhajeri and Fourcade, 2019). It is funded by various governments, agencies, corporations and foundations members organisations. IUCN Member Organizations set directions of Union's work and other global conservation efforts in detail, every four years at IUCN World Conservation Congress. IUCN Commissions is a broad network of over ten thousand of scientists and experts. Six commissions are framed by these experts as under: 
- Commission on Ecosystem Management

- Commission on Education and Communication

- Commission on Environmental, Economic and Social Policy

- Species Survival Commission

- World Commission on Environmental Law

- World Commission on Protected Area

IUCN Secretariat works on key themes related to conservation, environmental and ecological issues and it is organised into eleven operational regions.

\section{IUCN red list of threatened species}

The IUCN red list of threatened species was founded in 1964. It is used to assess the health of various species at the global level. It provides the precise, scientific, quantitative criteria to find out any threat to species that is relevant to most of the species and all the regions of the world.

- Over 134,425 species have been assessed.

- 37,400 plus are classified as threatened with extinction.

- The current target is to assess 160,000 species out of which only 25,575 species remaining.

- The IUCN Red list is updated twice per year.

- $\quad$ The next publication date of the IUCN Red List is $4^{\text {th }}$ or $7^{\text {th }}$ of September, 2021.

\section{IUCN red list categories}

Following are the nine categories in IUCN red list (Figure 8).

- Not Evaluated (NE): The category of taxon is not decided because the taxon study has not been done.

- Data Deficient (DD): The taxon is studied thoroughly but there is less or no information about its distribution and population. Due to deficiency of data, it becomes difficult to decide what category it belongs in.

- Least Concern (LC): The taxon is widespread and fairly abundant so no need to place in threatened category.

- Near Threatened (NT): The taxon is not in the list of threatened categories but are likely to be included in vulnerable, endangered or critically endangered category in near future.

- Vulnerable (VU): Taxon are at the risk for being endangered.

- $\quad$ Endangered (EN): Taxon has high risk of extinction in wild.

- Critically Endangered (CR): Taxon has extremely high risk of extinction in wild.

- Extinct in the Wild (EW): Known to survive only in captivity, cultivation and or outside natural range.

- Extinct (EX): No known individuals of taxon are remaining. 


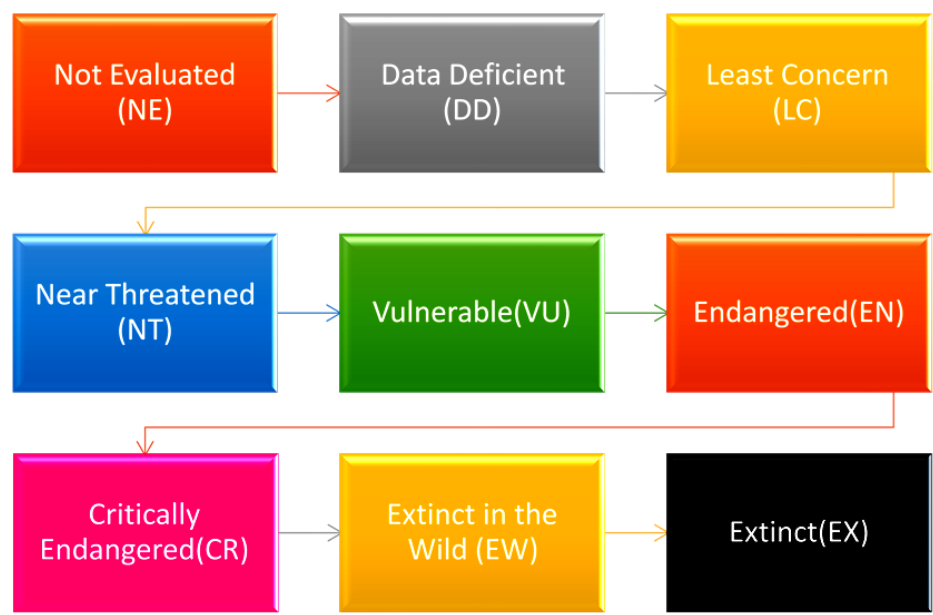

Figure 8. IUCN red list categories.

\section{Conservation of biological diversity}

There are two main strategies for conservation of biological diversity (Sayer et al., 2021). In Situ Conservation: It means the conservation of species in their natural habitat. For example, National parks, Wildlife sanctuaries, Conservation reserves and Community reserves. Ex Situ Conservation: It means conservation of species or live parts of species outside their natural habitat. E.g., In- Vitro storage, Gene banks, Botanical and Zoological Gardens.

\section{In-situ conservation methods}

National parks: In India, currently there are 104 national parks in India (Table 4) covering a region of $43,716 \mathrm{~km}^{2}$, which is $1.33 \%$ of the geographical region of the country (National Wildlife Database, 2020). Wildlife sanctuaries: Currently there are 566 existing wildlife sanctuaries in India covering an area of 122420 square kilometre which constitutes $3.72 \%$ of the geographical area of India (Sahoo and Pradhan, 2021) (Table 5).

Conservation reserves: In India there are about 97 existing Conservation Reserves covering an area of 44483 square kilometres (Table 6).

Community reserves: Currently there are 214 existing Community Reserves in India (Table 7). These community reserves are playing significant role in the conservation of biological diversity (flora and fauna) of the country. In this, Nagaland has the maximum number of community reserves (Puri et al., 2019).

\section{Ex-situ conservation method}

It is the conservation method in which conservation of plants and animals is done outside their natural 
Table 4. State-wise distribution of National Parks, in India (Source: Wildlife Institute of India).

\begin{tabular}{|c|c|c|}
\hline State/ UT & Number of national parks & National park area $\left(\mathrm{km}^{2}\right)$ \\
\hline Andhra Pradesh & 3 & 1368.87 \\
\hline Arunachal Pradesh & 2 & $2,290.82$ \\
\hline Assam & 5 & $1,977.79$ \\
\hline Bihar & 1 & 335.65 \\
\hline Chhattisgarh & 3 & $2,899.08$ \\
\hline Goa & 1 & 107.00 \\
\hline Gujarat & 4 & 480.12 \\
\hline Haryana & 2 & 48.25 \\
\hline Himachal Pradesh & 5 & $2,256.28$ \\
\hline Jharkhand & 1 & 226.33 \\
\hline Karnataka & 5 & $2,794.05$ \\
\hline Kerala & 6 & 558.16 \\
\hline Madhya Pradesh & 11 & 4349.14 \\
\hline Maharashtra & 6 & $1,273.60$ \\
\hline Manipur & 2 & 140.00 \\
\hline Meghalaya & 2 & 267.48 \\
\hline Mizoram & 2 & 150.00 \\
\hline Nagaland & 1 & 202.02 \\
\hline Odisha & 2 & 990.70 \\
\hline Punjab & 0 & 0.00 \\
\hline Rajasthan & 5 & $3,947.07$ \\
\hline Sikkim & 1 & $1,784.00$ \\
\hline Tamil Nadu & 5 & 827.51 \\
\hline Telangana & 3 & 19.62 \\
\hline Tripura & 2 & 36.71 \\
\hline Uttar Pradesh & 1 & 490.00 \\
\hline Uttarakhand & 6 & $4,915.02$ \\
\hline West Bengal & 6 & $1,981.48$ \\
\hline Andaman \& Nicobar & 6 & $1,216.95$ \\
\hline Chandigarh & 0 & 0.00 \\
\hline Dadra \& Nagar Haveli & 0 & 0.00 \\
\hline Daman \& Diu & 0 & 0.00 \\
\hline Delhi & 0 & 0.00 \\
\hline Jammu \& Kashmir & 4 & 2432.45 \\
\hline Ladakh & 1 & 3350.00 \\
\hline Lakshadweep & 0 & 0.00 \\
\hline Puducherry & 0 & 0.00 \\
\hline Total & 104 & 43,716 \\
\hline
\end{tabular}


Table 5. State-wise distribution of Wildlife sanctuaries in India (Source: Wildlife Institute of India).

\begin{tabular}{|c|c|c|}
\hline State/UT & Total number of wildlife sanctuaries & Total area (In sq.km.) \\
\hline Andhra Pradesh & 13 & 8008.49 \\
\hline Arunachal Pradesh & 11 & 7487.75 \\
\hline Assam & 18 & 1840.14 \\
\hline Bihar & 12 & 2901.68 \\
\hline Chhattisgarh & 11 & 3760.28 \\
\hline Goa & 6 & 647.91 \\
\hline Gujarat & 23 & 16574.42 \\
\hline Haryana & 8 & 233.21 \\
\hline Himachal Pradesh & 28 & 6116.1 \\
\hline Jammu \&Kashmir & 15 & 10243.11 \\
\hline Jharkhand & 11 & 1955.81 \\
\hline Karnataka & 30 & 6774.81 \\
\hline Kerala & 17 & 1928.24 \\
\hline Madhya Pradesh & 25 & 7958.4 \\
\hline Maharashtra & 42 & 7604.44 \\
\hline Manipur & 2 & 184.81 \\
\hline Meghalaya & 4 & 94.1 \\
\hline Mizoram & 8 & 1090.75 \\
\hline Nagaland & 3 & 20.33 \\
\hline Odisha & 19 & 6969.15 \\
\hline Punjab & 13 & 326.6 \\
\hline Rajasthan & 25 & 5379.26 \\
\hline Sikkim & 7 & 399.1 \\
\hline Tamil Nadu & 29 & 6157.12 \\
\hline Tripura & 4 & 566.93 \\
\hline Uttar Pradesh & 25 & 5828.36 \\
\hline Uttarakhand & 7 & 2690.05 \\
\hline West Bengal & 15 & 1442.12 \\
\hline Telangana & 9 & 7077.72 \\
\hline Andaman and Nicobar Islands & 96 & 389.39 \\
\hline Chandigarh & 2 & 26.01 \\
\hline Dadar \& Nagar & 1 & 92.16 \\
\hline \multicolumn{3}{|l|}{ Haweli } \\
\hline Lakshadweep & 1 & 2.18 \\
\hline Daman \& Diu & 1 & 27.82 \\
\hline Delhi & 1 & 0.01 \\
\hline Pondicherry & 1 & 3.9 \\
\hline
\end{tabular}

habitat under special settings in which extra care is done. There are many species of plants and animals which are extinct in wild but are preserved under captivities. Ex-Situ conservation is an important conservation method when In-situ conservation method are not sufficient (Hoban et al., 2020). This method has become more advanced now seeds, plantlets, eggs, semen, ovules, embryo, DNA and pollens are preserved by using various techniques. Botanical gardens, zoological parks, field gene banks, tissue culture banks, In vitro and in vivo preservation are some of the examples of ex situ method of biological diversity conservation Perrino and Wagensommer, 2021). 
Table 6. State-wise breakup of Conservation Reserve in India (Source: Wildlife Institute of India).

\begin{tabular}{lll}
\hline State/UT & No. of conservation reserves & Area $\mathbf{( k m}^{\mathbf{2}} \mathbf{~}$ \\
\hline Gujarat & 1 & 227.00 \\
Himachal Pradesh & 3 & 19.17 \\
Karnataka & 14 & 171.92 \\
Maharashtra & 7 & 490.05 \\
Punjab & 4 & 25.71 \\
Rajasthan & 14 & 655.37 \\
Sikkim & 1 & 0.06 \\
Tamil Nadu & 2 & 4.88 \\
Uttarakhand & 4 & 212.45 \\
West Bengal & 5 & 1415.91 \\
Jammu \& Kashmir & 32 & 692.88 \\
Ladakh & 5 & 249.00 \\
Lakshadweep & 3 & 270.05 \\
Total & 97 & 4483 \\
\hline
\end{tabular}

Table 7. State-wise distribution of Community Reserves in India (Source: Wildlife Institute of India).

\begin{tabular}{lll}
\hline State/UT & No. of Community Reserves & Area $\mathbf{( k m}^{\mathbf{2}} \mathbf{~}$ \\
\hline Arunachal Pradesh & 9 & 131.60 \\
Haryana & 5 & 115.84 \\
Karnataka & 1 & 3.12 \\
Kerala & 1 & 1.50 \\
Manipur & 10 & 103.72 \\
Meghalaya & 71 & 64.93 \\
Nagaland & 114 & 851.78 \\
Punjab & 3 & 29.02 \\
Total & 214 & 1302 \\
\hline
\end{tabular}

Table 8. Major sites for conservation of biodiversity in India (Source: www.wiienvis.nic.in).

\begin{tabular}{ll}
\hline Site name & Total Number \\
\hline Tiger Reserves & 51 \\
Elephant Reserves & 32 \\
RAMSAR Wetland Sites & 46 \\
Important Coastal and Marine Biodiversity Areas & 107 \\
(ICBMs) & \\
Important Bird Areas (IBAs) & 467 \\
Biosphere Reserves & 18 \\
Biodiversity Heritage Sites & 18 \\
\hline
\end{tabular}


Zoological Park: It is the open, semi- closed and semi- natural place where animals are kept for the conservation purposes. The animals are provided with proper food, medical care and good hygiene. It is a source of economy as many people visit to see these rare and endangered animals. It is also helpful for research and academic purposes. There are about 147 recognised zoological parks in India (Kumar and Verma, 2017).

Botanical Garden: It is the place where different types of wild and threatened plants are grown or the parts of plants are conserved. It is very helpful for conserving plants diversity. It can be used as a source of economy, scientific research, plant monitoring and a place for biodiversity awareness. The proper care and monitoring of plant species have been done so that species can be re-introduced in their natural habitat. In India, there are about 13 botanical gardens (Baber, 2016).

Seed Banks: These are very helpful for conserving different variety of seeds. Less space is required for conserving seeds and the favourable climate is maintained according to the need and nature of seed. But it is not useful for recalcitrant seeds (Peres, 2016).

Aquarium: It is used to conserve the species which live in water. Many species of fishes, aquatic animals and amphibians are endangered. It is used to provide food, protection and breeding is done so that it can be re- introduced in their natural habitat (Cracknell et al., 2016).

In-vivo and In-vitro conservation: These methods of conservation deal with threatened or endangered species and high value species. Here conservation of genes is done by preserving seeds, vegetative propagules, cells and tissue culture. Cryopreservation (in which liquid nitrogen with temperature minus $196{ }^{\circ} \mathrm{C}$ ) for preservation and gene transforming methods are used in this type of ex situ conservation method (Hiromoto et al., 2015).

Sites of conservation importance: Besides this, the biodiversity of India has also been protected through the construction of tiger reserves, elephant reserves, RAMSAR wetland sites, Biosphere reserves, and biodiversity heritage sites that are distributed in the different part of the country. Here is the list of few more important sites of conservation importance with total number of sites present in India (Table 8).

\section{Conclusion}

Biological diversity/biodiversity is the variety of lifeforms present on the planet. It is of immense importance for mankind. It provides various ecological services needed by human beings. Also, biodiversity provides us with various things of moral and economical importance. The overexploitation as well as change in the climatic conditions have contributed in the threatening of biodiversity. Moreover, the inappropriate utilization of biodiversity for its commercial value is heading towards its depletion in much faster way. Many ecologically important organisms/plants have become extinct because of their overutilization/overexploitation such as Dodo (Raphus cucullatus) and Woolly Mammoth (Mammuthus primigenius). Nowadays, many conservation methods like in-situ and ex-situ conservation are being adopted to save the available species especially which are at the verge of extinction. Therefore, this book chapter deals with the values, threats and conservation measured for the biodiversity in an elaborative manner. 


\section{References}

Alhajeri, B. H. and Fourcade, Y. (2019). High correlation between species-level environmental data estimates extracted from IUCN expert range maps and from GBIF occurrence data, Journal of Biogeography, 46(7): 1329-1341, https:// doi.org/10.1111/jbi.13619

Antonelli, A. and Perrigo, A. (2018). The science and ethics of extinction. Nature ecology $\mathcal{E}$ evolution, 2(4), 581-581, https:// doi.org/10.1038/s41559-018-0500-Z

Baber, Z. (2016). The plants of empire: Botanic gardens, colonial power and botanical knowledge. Journal of Contemporary Asia, 46(4): 659-679, https:// doi.org/10.1080/00472336.2016.1185796

Bailey, S.A. (2015). An overview of thirty years of research on ballast water as a vector for aquatic invasive species to freshwater and marine environments. Aquatic Ecosystem Health $\mathcal{E}$ Management, 18(3): 261-268, https:// doi.org/10.1080/14634988.2015.1027129

Bartkowski, B., Lienhoop, N. and Hansjürgens, B. (2015). Capturing the complexity of biodiversity: A critical review of economic valuation studies of biological diversity. Ecological Economics, 113: 1-14, https://doi.org/10.1016/ j.ecolecon.2015.02.023

Basumatary, S.K., Tripathi, S., Bera, S.K., Nautiyal, C.M., Devi, N. and Sarma, G.C. (2015). Late Pleistocene palaeoclimate based on vegetation of the Eastern Himalayan foothills in the Indo-Burma Range, India. Palynology, 39(2): 220-233, https:// doi.org/10.1080/01916122.2014.945665

Brei, M., Pérez-Barahona, A. and Strobl, E. (2016). Environmental pollution and biodiversity: Light pollution and sea turtles in the Caribbean. Journal of Environmental Economics and Management, 77: 95-116.

Brierley, G.J., Li, X., Cullum, C. and Gao, J. (2016). Introduction: landscape and ecosystem diversity in the Yellow River Source Zone. In Landscape and ecosystem diversity, dynamics and management in the Yellow River Source Zone (pp. 1-34). Springer, Cham.

BSI (2014). Botanical Survey of India, Annual report 2014-15. Retrieved from https://bsi.gov.in/uploads/documents/ reports/annualReportBsi/english/Annual\%20Report\%202014-15_.pdf

Buchanan, M. (2021). Nature fights back. Nature Physics, 17, 758.

Carvalho, Y.G., Vitorino, L.C., de Souza, U. J. and Bessa, L.A. (2019). Recent trends in research on the genetic diversity of plants: Implications for conservation. Diversity, 11(4): 62, https://doi.org/10.3390/d11040062

Collins, R., Schaafsma, M. and Hudson, M.D. (2017). The value of green walls to urban biodiversity. Land Use Policy, 64, 114123.

Cracknell, D., White, M.P., Pahl, S., Nichols, W.J. and Depledge, M.H. (2016). Marine biota and psychological well-being: a preliminary examination of dose-response effects in an aquarium setting. Environment and Behavior, 48(10): 1242-1269, https://doi.org/10.1177/0013916515597512

de Souza, A.C. and Prevedello, J.A. (2020). The importance of protected areas for overexploited plants: Evidence from a biodiversity hotspot. Biological Conservation, 243: 108482, https://doi.org/10.1016/j.biocon.2020.108482

Díaz, Sandra, Andy, H. and Wardle, D.A. (2009). Biodiversity in forest carbon sequestration initiatives: Not just a side benefit. Current Opinion in Environmental Sustainability, 1(1): 55-60, https://doi.org/10.1016/j.cosust.2009.08.001

Dietsch, A.M., Teel, T.L. and Manfredo, M.J. (2016). Social values and biodiversity conservation in a dynamic world. Conservation Biology, 30(6): 1212-1221, https://doi.org/10.1111/cobi.12742

Evers, C.R., Wardropper, C.B., Branoff, B., Granek, E.F., Hirsch, S.L., Link, T.E. and Wilson, C. (2018). The ecosystem services and biodiversity of novel ecosystems: A literature review. Global Ecology and Conservation, 13: e00362, https:// doi.org/10.1016/j.gecco.2017.e00362

Fortelius, M. and Kappelman, J. (1993). The largest land mammal ever imagined. Zoological Journal of the Linnean Society. 108: 85-101, https://doi.org/10.1111/j.1096-3642.1993.tb02560.x.

Gaston, Kevin J., Spicer and John, I. (2004). Biodiversity: An Introduction. Wiley. ISBN 978-1-4051-1857-6.

Gonzalez, A., Cardinale, B.J., Allington, G.R., Byrnes, J., Arthur Endsley, K., Brown, D.G. and Loreau, M. (2016). Estimating 
local biodiversity change: a critique of papers claiming no net loss of local diversity. Ecology, 97(8): 1949-1960, https:// doi.org/10.1890/15-1759.1

Griffiths, V.F., Bull, J.W., Baker, J. and Milner-Gulland, E.J. (2019). No net loss for people and biodiversity. Conservation Biology, 33(1): 76-87, https://doi.org/10.1111/cobi.13184

Gupta, N., Tiwari, V., Everard, M., Savage, M., Hussain, S.A., Chadwick, M.A. and Belwal, V.K. (2020). Assessing the distribution pattern of otters in four rivers of the Indian Himalayan biodiversity hotspot. Aquatic Conservation: Marine and Freshwater Ecosystems, 30(3): 601-610.

Hanley, N., Breeze, T.D., Ellis, C. and Goulson, D. (2015). Measuring the economic value of pollination services: Principles, evidence and knowledge gaps. Ecosystem Services, 14: 124-132, https://doi.org/10.1016/j.ecoser.2014.09.013

Hiromoto, S., Inoue, M., Taguchi, T., Yamane, M. and Ohtsu, N. (2015). In vitro and in vivo biocompatibility and corrosion behaviour of a bioabsorbable magnesium alloy coated with octacalcium phosphate and hydroxyapatite. Acta biomaterialia, 11: 520-530, https://doi.org/10.1016/j.actbio.2014.09.026

Hoban, S., Callicrate, T., Clark, J., Deans, S., Dosmann, M., Fant, J. and Griffith, M.P. (2020). Taxonomic similarity does not predict necessary sample size for ex situ conservation: A comparison among five genera. Proceedings of the Royal Society B, 287(1926): 20200102, https://doi.org/10.1098/rspb.2020.0102

Hu, X., Huang, B., Verones, F., Cavalett, O. and Cherubini, F. (2021). Overview of recent land-cover changes in biodiversity hotspots. Frontiers in Ecology and the Environment, 19(2): 91-97, https://doi.org/10.1002/ fee.2276

Huang, D., Goldberg, E.E., Chou, L. M. and Roy, K. (2018). The origin and evolution of coral species richness in a marine biodiversity hotspot. Evolution, 72(2): 288-302, https://doi.org/10.1111/evo.13402

Jactel, H., Gritti, E.S., Drössler, L., Forrester, D.I., Mason, W.L., Morin, X. and Castagneyrol, B. (2018). Positive biodiversityproductivity relationships in forests: climate matters. Biology Letters, 14(4): 20170747.

Johnson, K.G., Hasibuan, F., Mueller, W. and Todd, J.A. (2015). Biotic and environmental origins of the southeast Asian marine biodiversity hotspot: The throughflow project. Palaios, 30(1): 1-6.

Kamal, S. Bawa, Da, A. and Krishnaswamy, J. (2007), Western Ghats \& Sri Lankan Biodiversity Hotspot. Critical Ecosystem Partnership Fund Conservation International 2011 Crystal Drive Suite 500 Arlington, VA 22202, USA.

Kano, Y., Dudgeon, D., Nam, S., Samejima, H., Watanabe, K., Grudpan, C. and Utsugi, K. (2016). Impacts of dams and global warming on fish biodiversity in the Indo-Burma hotspot. PloS one, 11(8): e0160151.

Kiran, M., Caboň, M., Senko, D., Khalid, A.N. and Adamčík, S. (2021). Description of the Fifth New Species of Russula subsect. Maculatinae from Pakistan Indicates Local Diversity Hotspot of Ectomycorrhizal Fungi in Southwestern Himalayas. Life, 11(7): 662.

Kumar, A. and Verma, A.K. (2017). Biodiversity loss and its ecological impact in India. International Journal on Biological Sciences, 8(2): 156-160.

Kumar, V. and Chopra, A.K. (2009). Impact of climate change on biodiversity of India with special reference to Himalayan region-An overview. Journal of Applied and Natural Science, 1(1): 118-122, https://doi.org/10.31018/jans.v1i1.48

Kumar, V., Kumar, P. and Singh, J. (2019). An introduction to contaminants in agriculture and environment. In: Contaminants in Agriculture and Environment: Health Risks and Remediation, 1: 1-8.

Mora, C., Tittensor, D.P., Adl, S., Simpson, A.G.B. and Worm, B. (2011). How many species are there on earth and in the ocean? PLoS., Biology 9(8): e1001127. https://doi.org/10.1371/journal.pbio.1001127

Myers, N., Mittermeier R.A., Mittermeier, C.G., Da Fonseca, G.A.B. and Kent, J. (2000). Biodiversity hotspots for conservation priorities. Nature, 403: 853-858, https://doi.org/10.1038/35002501

NOSS, R.F. (1990). Indicators for Monitoring Biodiversity: A Hierarchical Approach. Conservation Biology, 4(4): 355-364. https://doi.org/10.1111/j.1523-1739.1990.tb00309.x

Oliver, T.H. and Morecroft, M.D. (2014). Interactions between climate change and land use change on biodiversity: attribution problems, risks, and opportunities. Wiley Interdisciplinary Reviews: Climate Change, 5(3): 317-335, https:// doi.org/10.1002/wcc. 271

Peres, S. (2016). Saving the gene pool for the future: Seed banks as archives. Studies in History and Philosophy of Science Part C: Studies in History and Philosophy of Biological and Biomedical Sciences, 55, 96-104. 
Perrino, E.V. and Wagensommer, R.P. (2021). Crop wild relatives (CWR) priority in Italy: Distribution, ecology, in situ and ex situ conservation and expected actions. Sustainability, 13(4): 1682, https://doi.org/10.3390/su13041682

Puri, M., Karanth, K.K. and Thapa, B. (2019). Trends and pathways for ecotourism research in India. Journal of Ecotourism, 18 (2), 122-141: https://doi.org/10.1080/14724049.2018.1474885

Rana, S.K., Luo, D., Rana, H.K., O'Neill, A.R. and Sun, H. (2021). Geoclimatic factors influence the population genetic connectivity of Incarvillea arguta (Bignoniaceae) in the Himalaya-Hengduan Mountains biodiversity hotspot. Journal of Systematics and Evolution, 59(1): 151-168.

Sahoo, M. and Pradhan, J. (2021). Adaptation and Acculturation: Resettling displaced tribal communities from wildlife sanctuaries in India. Migration Letters, 18(3): 237-259, https://doi.org/10.33182/ml.v18i3.877

Sarkar, S. (2019). What Should “Biodiversity" Be?. In: Casetta E., Marques da Silva J., Vecchi D. (eds) From Assessing to Conserving Biodiversity. History, Philosophy and Theory of the Life Sciences, vol 24. Springer, Cham. https://doi.org/10.1007/978-3-030-10991-2_18

Sayer, J., Margules, C. and McNeely, J.A. (2021). People and biodiversity in the 21st Century. Ambio, 50(5), 970-975, https:// doi.org/10.1007/s13280-020-01476-9

Seddon, N., Mace, G.M., Naeem, S., Tobias, J.A., Pigot, A.L., Cavanagh, R. and Walpole, M. (2016). Biodiversity in the Anthropocene: prospects and policy. Proceedings of the Royal Society B: Biological Sciences, 283(1844): 20162094, https:// doi.org/10.1098/rspb.2016.2094

Sholihah, A. (2020). Diversification of Sundaland aquatic biotas: build-up of freshwater fishes' diversity and distribution in a biodiversity hotspot (Doctoral dissertation, Université Montpellier).

Singh, J.S. and Chaturvedi, R.K. (2017). Diversity of ecosystem types in India: a review. Proceeding of Indian National Science Academy, 83: 569-594.

Sivaperuman, C., Venkataraman, K. and Kumar, A. (2018). Endemic, Endangered and Threatened Vertebrates in the Indian Hotspots. In Indian Hotspots (pp. 29-56). Springer, Singapore.

Stephan, A., Suresh, R. and Livingstone, C. (2015). Indian Biodiversity: Past, Present and Future. International Journal of Environment and Natural Sciences, 7: 13-28.

Stoll-Kleemann, S. and Schmidt, U.J. (2017). Reducing meat consumption in developed and transition countries to counter climate change and biodiversity loss: a review of influence factors. Regional Environmental Change, 17(5): 1261-1277, https://doi.org/10.1007/s10113-016-1057-5

Thapa, S., Wang, L., Koirala, A., Shrestha, S., Bhattarai, S. and Aye, W.N. (2020). Valuation of ecosystem services from an important wetland of Nepal: A Study from Begnas watershed system. Wetlands, 40(5): 1071-1083, https:// doi.org/10.1007/s13157-020-01303-7

Titley, M.A., Snaddon, J.L. and Turner, E.C. (2017). Scientific research on animal biodiversity is systematically biased towards vertebrates and temperate regions. PloS one, 12(12): e0189577, https://doi.org/10.1371/journal.pone.0189577

Unwins, P.J.R., Webb, R.I. and Taylor, A.P. (1999). Novel Nano-organisms from Australian Sandstones. American Mineralogist, 83: 1541.

Venkataraman, K. and Sivaperuman, C. (2018). Biodiversity Hotspots in India: Vertebrate Faunal Diversity, Conservation and Management. Volume 2, Singapore: Springer

Verma, M., Symes, W.S., Watson, J.E., Jones, K.R., Allan, J.R., Venter, O. and Carrasco, L.R. (2020). Severe human pressures in the Sundaland biodiversity hotspot. Conservation Science and Practice, 2(3): e169, https://doi.org/10.1111/csp2.169

White, A., Fant, J.B., Havens, K., Skinner, M. and Kramer, A.T. (2018). Restoring species diversity: assessing capacity in the US native plant industry. Restoration Ecology, 26(4): 605-611, https://doi.org/10.1111/rec.12705

Wilcox, B.A. (1984). In situ conservation of genetic resources: determinants of minimum area requirements. In National Parks, Conservation and Development, Proceedings of the World Congress on National Parks, J.A. McNeely and K.R. Miller, Smithsonian Institution Press, pp. 18-30.

Yakovlev, R.V. and Zolotuhin, V.V. (2021). Revision of the family Metarbelidae (Lepidoptera) of the Oriental Region. II. Two monotypic genera-Ghatarbela gen. nov. and Micrarbela gen. nov. from the Western Ghats and Sri Lanka biodiversity hotspot. Ecologica Montenegrina, 42: 103-108. 
ZSI (2014). Zoological Survey of India, Prani Vigan Bhawan, M-Block, News Alipore Kolkata-700053, Retrieved from www.http;//www.zsi.gov.in/App/Index.aspx.

Cite this chapter as: Rani, S., Kumari, S., Kumar, P. and Kumar, V. (2021). Biological diversity: Introduction, values, threats and conservation measures. In: Biological Diversity: Current Status and Conservation Policies, Volume 1, Eds. Kumar., V., Kumar, S., Kamboj, N., Payum, T., Kumar, P. and Kumari, S. pp. 1-23, https://doi.org/10.26832/aesa2021-bdcp-01 